\title{
THE DETERMINANTS OF FINANCING OBSTACLES
}

\author{
Thorsten Beck, Aslı Demirgüç-Kunt, Luc Laeven, and Vojislav Maksimovic*
}

Keywords: Financing Constraints, Investment Models

JEL Classification: E22, G30, O16

World Bank Policy Research Working Paper 3204, February 2004

The Policy Research Working Paper Series disseminates the findings of work in progress to encourage the exchange of ideas about development issues. An objective of the series is to get the findings out quickly, even if the presentations are less than fully polished. The papers carry the names of the authors and should be cited accordingly. The findings, interpretations, and conclusions expressed in this paper are entirely those of the authors. They do not necessarily represent the view of the World Bank, its Executive Directors, or the countries they represent. Policy Research Working Papers are available online at http://econ.worldbank.org.

* Beck, Demirguc-Kunt and Laeven: World Bank; Maksimovic: Robert H. Smith School of Business at the University of Maryland. We would like to thank two anonymous referees for useful comments and suggestions. 


\section{THE DETERMINANTS OF FINANCING OBSTACLES}

Abstract: We use survey data on a sample of over 10,000 firms from 80 countries to assess (i) how successful a priori classifications are in distinguishing between financially constrained and unconstrained firms, and (ii) more generally, the determinants of financing obstacles of firms. We find that older, larger, and foreign-owned firms report less financing obstacles. Our findings thus confirm the usefulness of size, age and ownership as a priori classifications of financing constraints, while they shed doubts on other classifications used in the literature. Our results also suggest that institutional development is the most important country characteristic explaining cross-country variation in firms' financing obstacles. 


\section{Introduction}

Since a seminal paper by Fazzari, Hubbard and Petersen (1988) [henceforth, FHP], a large body of empirical literature has emerged to estimate financing constraints of firms (see the surveys by Schiantarelli 1995, Blundell, Bond and Meghir 1996, Hubbard 1998, and Bond and Van Reenen 1999). This literature relies on the assumption that external finance is more costly than internal finance due to asymmetric information and agency problems, and that the "premium" on external finance is an inverse function of a borrower's net worth. A firm is defined to be financially constrained if a windfall increase in the supply of internal funds results in a higher level of investment spending.

Following FHP, it is usually assumed that there are cross-sectional differences in effects of internal funds on firms' investment, so that investment follows the optimal path for a priori unconstrained firms but a sub-optimal path for constrained firms. Subsequently, researchers have applied different a priori classifications of firms to distinguish financially constrained and unconstrained firms.

In this paper, we use a unique firm-level survey database to focus on two questions. First, how successful are these a priori classifications in distinguishing between financially constrained and unconstrained firms? Second, and more generally, what are the determinants of financing obstacles of firms? The World Business Environment Survey (WBES) is a unique firm-level survey database, which offers a number of advantages. First, the database provides information on the firm's perception of the degree to which it is financially constrained or not. Therefore, unlike previous studies that inferred financing constraints from company financial statements using different methodologies, we can measure firms' financing obstacles directly from the data. Second, the database contains 
information on a broad cross-section of different types of firms in a large number of countries, including a large number of small and medium-sized enterprises. Therefore, unlike previous studies that focused either on a sample of large, listed firms, or on firms in a limited number of countries, we are able to study how financing obstacles differ not only across countries, but also across firm size. As smaller firms are generally considered to face larger financing obstacles, it seems particularly important to investigate this largely ignored segment of the firm population.

Our results indicate that many of the previously used a priori groupings are indeed effective in classifying financially constrained firms. However, we find that certain groupings are more effective than others. Specifically, age, size and ownership structure are effective categorizations of firms when studying financing obstacles; older, larger and foreign-owned firms report lower financing obstacles. Variables capturing these firm characteristics not only enter statistically significant in the regressions, but also explain large variations in firms' financing obstacles.

We also explore whether financial and economic development helps alleviate the financing obstacles of the firms that report to be most constrained. While we find that firms in countries with higher levels of financial intermediary development, stock market development, legal system efficiency and higher GDP per capita report, on average, lower financing obstacles, the underlying institutions driving both financial and economic development seem to be the most important country characteristic explaining cross-country variation in firms' financing obstacles.

While we explore the determinants of self-reported financing obstacles, we do not explore the relation between financing obstacles and the actual firm growth. While firms report and rate certain obstacles, not all of them might actually be binding constraints. 
Beck, Demirguc-Kunt and Maksimovic (2004) assess the importance of self-reported financing, legal and corruption obstacles for firm growth using the same data and find that many of these obstacles are indeed binding. They also explore the effect of firm size and financial and institutional development on the relation between the reported obstacles and growth. However, while Beck, Demirguc-Kunt and Maksimovic (2004) focus on the role of country-level financial and institutional development in overcoming the constraining effect of financing obstacles, we analyze firm characteristics that explain differences in reported financing obstacles.

The remainder of the paper is organized as follows. Section 2 presents the related literature and the motivation for our analysis. In section 3 we discuss the data and report summary statistics. Section 4 discusses the empirical methodology. Section 5 explores the firm characteristics that predict financing obstacles. Section 6 explores the effect of country-level financial and institutional development on financing obstacles and section 7 concludes.

\section{Related Literature and Motivation}

Since the work by FHP, several methodologies have been suggested to test empirically the presence of financing constraints. Following FHP, most studies derive an empirical specification from the firm's investment Euler equation that describes the firm's optimal investment pattern. One model is the q-model of investment, pioneered by Tobin (1969) and extended to models of investment by Hayashi (1982). Financial frictions are introduced to the model by adding financial variables such as cash flow. An alternative approach, introduced by Abel (1980), is to derive an empirical specification from the firm's investment Euler equation describing the firm's optimal investment pattern. The Euler 
model of investment has been applied and further developed by Abel and Blanchard (1986), Bond and Meghir (1994), and Gilchrist and Himmelberg (1994, 1998), among others. A third approach, introduced by Demirgüç-Kunt and Maksimovic (1998), estimates a financial planning model to obtain the maximum growth rate firms can attain without access to external finance. By comparing these growth rates with the actual growth rates of firms, they are able to infer the degree to which firms are financially constrained.

The first two approaches basically imply that financially constrained firms have high investment-cash flow sensitivity. Kaplan and Zingales $(1997,2000)$ question the validity of this interpretation. They show that under certain assumptions, investment-cash flow sensitivities may increase as financing constraints are relaxed. Almeida and Campello (2001) draw similar conclusions. Povel and Raith (2002) find a U-shaped relationship between cash flow and investment, further adding to the controversy about the interpretation of cash-flow sensitivities. There also exist a number of methodological problems with these two approaches. For example, Gomes (2001) shows that if cash flow is a good proxy for future investment opportunities, significant investment-cash flow sensitivities could arise even in the absence of financial frictions. More generally, Bond and Van Reenen (1999) point out that investment-cash flow sensitivities could also be indicating other sources of misspecification in the underlying investment models.

Following FHP it is usually assumed that there are cross-sectional differences in effects of internal funds on firms' investment, so that the investment equation should hold across adjacent periods for a priori unconstrained firms but be violated for constrained firms. This has led researchers to develop different a priori classifications of firms to distinguish financially constrained and unconstrained firms. From a theoretical point of view such sorting criteria should focus on a firm's characteristics that are associated with 
information costs. At the firm level, empirical studies have grouped firms by dividend payouts (FHP), business group affiliation (Hoshi, Kashyap, and Scharfstein 1991), size and age (Devereux and Schiantarelli 1990), the presence of bond ratings (Whited 1992), the degree of shareholder concentration, or the pattern of insider trading (Oliner and Rudebusch 1992). Previous work has also identified a number of determinants of financing constraints at the country level. Demirgüç-Kunt and Maksimovic (1998) find that financing constraints are lower in countries with more efficient legal systems. Love (2003) finds a strong negative relationship between the sensitivity of investment to the availability of internal funds and an indicator of financial market development, and concludes that financial development reduces the effect of financing constraints on investment. Laeven (2003) and Gelos and Werner (2002) find that financial liberalization relaxes financing constraints of firms, in particular for smaller firms.

Kaplan and Zingales (1997) classify firms into categories of "not financially constrained" to "financially constrained" based upon statements contained in annual reports. They classify firms as being severely financially constrained if these companies are in violation of debt covenants, have been cut out of their usual source of credit, are renegotiating debt payments, or declare that they are forced to reduce investments because of liquidity problems. Unfortunately, the problem with their analysis is that it is difficult to make such classifications based on information contained in annual reports. Fazzari, Hubbard and Petersen (2000) note that the firm-years Kaplan and Zingales (1997) classify as most financially constrained are actually observations from years when firms are financially distressed.

Our analysis contributes to the existing literature in two ways. First, by using survey data on a firm's perceived level of financing obstacles, we avoid having to imperfectly 
infer financing constraints from financial statements of firms as in FHP and Kaplan and Zingales (1997). This allows us to not only test the validity of the a priori group classifications used in the literature to distinguish between financially constrained and unconstrained firms, but also to assess more accurately the determinants of financing obstacles. Second, as the database includes firms of all sizes from a large number of countries with different levels of institutional development, we can determine more precisely the most important firm-level predictors of financing obstacles.

The WBES includes a number of firm characteristics that we will relate to financing obstacles as reported by the firms themselves. Each of the firm characteristics we focus on in our tests has been used in the literature as proxy for information asymmetries or agency costs to split samples of firms a priori into groups of financially constrained and unconstrained firms. First, we will test whether size or age predicts financing obstacles. The literature has proposed that smaller and younger firms are financially more constrained. For example, Gertler (1988) argues that information asymmetries are likely to be especially large for young and newly-established firms, because creditors have not had enough time to monitor such firms and because such firms have not had enough time to build long-term relationships with suppliers of finance. Devereux and Schiantarelli (1990) and Oliner and Rudebusch (1992), among others, have used age and size as a criteria to classify firms into groups of financially constrained and unconstrained firms. Schiffer and Weder (2001) have used the WBES survey to study how obstacles to doing business vary across firms of different size and report, among others, that perceived financing obstacles 
are higher for small firms than for large firms. ${ }^{1}$ We measure size by either the log of sales or dummy variables indicating whether the firm is small, medium or large.

We also test whether stock market listing or business-group affiliation is correlated with financing obstacles. The literature has proposed that information asymmetries of listed firms are smaller on average due to the listing and reporting requirements of stock exchanges (Oliner and Rudebusch 1992), and we therefore expect that firms that are listed on a stock exchange face lower financing obstacles. Firms that belong to a business group are conjectured to face lower financing obstacles, because these firms have access to the internal cash flow of the group (Shin and Park 1999) and because these firms are more likely to have close ties with banks (Hoshi, Kashyap, and Scharfstein 1991).

We also test whether geographical activity or ownership can explain differences in the reporting of financing obstacles. Multinational or foreign-owned enterprises have easier access to international sources of external financing and are therefore expected to report lower financing obstacles (Sembenelli and Schiantarelli 1996, and Harrison and McMillan 2003). Government-owned enterprises are also expected to report lower financing obstacles since in many countries they receive direct budgetary support from the government and preferential treatment by government-owned financial institutions (Harrison and McMillan 2003, and Laeven 2003).

Since the WBES does not provide information on firms' dividend payouts, we unfortunately cannot test whether firms with higher dividend payouts report lower financing obstacles, as presumed a priori in FHP. To control for the fact that country- or sector-specific characteristics might drive the responses of the firms, we will include sector

\footnotetext{
${ }^{1}$ Schiffer and Weder consider the relation between firm size and different obstacles, such as financing, corruption, infrastructure and macroeconomic policies. Unlike them, we focus on financing obstacles and unlike them we consider a wide array of firm characteristics.
} 
and country dummies in the regression analysis and allow for correlation between error terms of firms within countries.

Our methodology has the disadvantage of relying on unaudited self-reporting by firms. Thus, it is possible that while firms report financing obstacles, they are actually not constrained by them. However, Beck, Demirguc-Kunt and Maksimovic (2004) show that many of these financing obstacles are related to firms' growth rates, in the sense that firms that report financing obstacles tend to be growth-constrained. In order to distinguish the self-reported constraints from actual constraints, we will refer to the former as obstacles.

\section{Data}

The firm-level data are taken from the World Business Environment Survey (WBES) which is a major firm-level survey conducted in 1999 and 2000 in 80 developing and developed countries around the world and led by the World Bank. ${ }^{2}$ The main purpose of the survey was to identify obstacles to firm performance and growth around the world. Thus, the survey contains a large number of questions on the nature and severity of obstacles, such as infrastructure, crime, macroeconomic policies, corruption, legal system deficiencies and financing. The database also has information on firms' characteristics, such as ownership, sales, employment, and growth. The data also indicate whether a firm is a multinational enterprise, i.e. whether it has operations in other countries, and the sector in which the firm is producing. In total, over 10,000 firms were surveyed, with the number varying across countries but with a minimum of 100 firms per country. The sample of

\footnotetext{
${ }^{2}$ The World Bank created the steering committee of the WBES and many other developed and developing country agencies were involved under the supervision of EBRD and Harvard Center for International Development.
} 
surveyed firms in each country was constructed to reflect the sectoral, ownership and size structure. Data were mostly collected through personal interviews. ${ }^{3}$

Table I reports the composition of our sample according to size, ownership and other firm characteristics. An important strength of the database is its broad coverage of small and medium firms; 80 percent of the firms included in the survey are classified as small ( 5 to 50 employees) or medium (51 to 500 employees), while 20 percent are classified as large (more than 500 employees). Nearly 40 percent of our firms are in the service sector, while more than 30 percent are in the manufacturing sector. Only 10 percent of the firms are listed and even less are owned by business groups. Around 18 percent are multinational enterprises and a similar number of firms are foreign owned. Around 12 percent of all firms are government owned. Table A1 reports the number of firms for each country in our sample.

In Table I we also report the average reported financing obstacle for each firm group. Management of the surveyed firms was asked to rate how problematic financing is for the operation and growth of their business. The perceived severity of the obstacles was quantified by assigning them values between 4 , major obstacle, and 1 , no obstacle. $36 \%$ of all firms rate financing as major obstacle, $27 \%$ as moderate, $18 \%$ as minor and $19 \%$ as no obstacle. On average, larger, agricultural, non-listed, non-group-owned, national, domestically owned and government-owned firms report larger financing constraints.

Some of these differences are also economically significant. Take the example of firm size. The "average financing obstacle" for small and medium firms is 2.87 and 2.85 , respectively, while it is 2.59 for large firms. This translates into a $38.5 \%(37.7 \%)$ probability for small (medium) firms that they rate financing as major obstacle, while it

\footnotetext{
${ }^{3}$ For a more detailed discussion of the survey, see Batra, Kaufmann and Stone (2002). The data and documentation are available at http://info.worldbank.org/governance/wbes/index.html\#wbes.
} 
translates into a $28.5 \%$ probability for large firms. ${ }^{4}$ Of course, this simulation does not control for other firm characteristics.

Table II provides summary statistics. In addition to the financial obstacle described above, firms were also asked more detailed questions to understand the nature of obstacles in the financial sector better. These questions relate to: (a) collateral requirements of banks and financial institutions, (b) bank paperwork and bureaucracy, (c) high interest rates, (d) need for special connections with banks and financial institutions, (e) banks' lack of money to lend, (f) access to foreign banks, (g) access to non-bank equity, (h) access to export finance, (i) access to financing for leasing equipment, (j) inadequate credit and financial information on customers, (k) access to long-term loans, and (l) whether corruption of bank officials creates a problem.

High interest rates top the lists of specific financial obstacles, followed by the lack of access to long-term loans. ${ }^{5}$ More than half of the firms in our sample rate high interest rates as a major obstacle. Corruption of bank officials, on the other hand, is rated as only a minor obstacle. More than half of all surveyed firms rate it as no obstacle.

We also include several country-level variables in our analysis, all of which are averaged over the period 1995-99. As indicators of financial development we use private credit, value traded and law and order. Private credit is an indicator of financial intermediary development and equals the claims of financial institutions on the private

\footnotetext{
${ }^{4}$ To obtain these probabilities, we run an ordered probit regression on dummy variables for small and medium firms and then calculate the probability that small, medium and large firms report financing as major obstacle.

${ }^{5}$ To assess whether the responses to the survey question on interest rates simply reflect high interest rates in general (both deposit and lending rates) or a high wedge between deposit and lending rates, we explore correlations with bank- and country-level indicators of interest margins and spreads. The correlation between high interest rates and the net interest rate margins as share of assets is $50 \%$, significant at the $1 \%$ level. The correlation with the interest spread, the difference between average lending and average deposit rate, is $55 \%$. This significant relationship holds even after controlling for the level of real lending interest rates. Data on margins and spreads are from Bankscope and International Financial Statistics, respectively.
} 
sector as a share of GDP. Value traded is an indicator of stock market development and equals the total volume traded on stock exchanges relative to GDP. Both private credit and value traded have been shown to have a causal relation with economic growth (Beck, Levine, and Loayza 2000 and Beck and Levine 2003). Law and order is an indicator of the efficiency of the legal systems and indicates the degree to which citizens of a country trust the legal system to resolve disputes. Institutional development is an aggregate indicator of the institutional environment in which firms operate. The underlying data are from Kaufman, Kraay and Mastruzzi (2003) and include information on voice and accountability in the political system, the quality and consistency of regulations and regulatory enforcement in the country, political stability, the rule of law, the lack of official corruption, and the effectiveness the government bureaucracy. ${ }^{6}$ Both law and order and institutional development increase in legal system efficiency and institutional development, respectively. Finally, we include GDP per capita to measure economic development. Table A1 lists the values for all five variables for the countries in our sample. Table II shows that there is a large variation in financial development across countries, ranging from Ukraine (0.01) to the U.S. (1.63) for the case of private credit.

Panel B of Table II shows the correlation matrix between the general financing obstacle and the different firm characteristics we are considering. ${ }^{7}$ Small and medium firms report significantly higher financing obstacles than large firms, while financing obstacles decrease in the age of the enterprise. Agricultural and construction firms seem to face higher obstacles, whereas service firms report significantly lower financing obstacles. The reported obstacles are significantly lower for listed firms, group-owned firms,

\footnotetext{
${ }^{6}$ Unlike law and order, which focuses on legal system efficiency, institutional development is a much broader indicator.

${ }^{7} \mathrm{We}$ do not include the correlations between the country characteristics, which are all positively and significantly correlated with each other.
} 
multinationals, foreign-owned and privately-owned firms. However, we also note that many of these firm characteristics are correlated with each other. Firms in manufacturing tend to be larger, as are listed firms and enterprises that are part of a business group. Older firms tend to be larger, in manufacturing rather than in the service or construction industry, more likely to be listed, part of a business group, a multinational enterprise and foreign or government-owned firm. Listed firms are more likely to be owned by foreign owners or the government. In order to determine which firm characteristics explain variation in financing obstacles, we therefore conduct multivariate analysis.

\section{Empirical Model}

The simple statistics presented in section 3 indicate that there are significant relations between firms' financing obstacles and their characteristics. While these simple correlations are suggestive, they do not control for potentially confounding variables. We assume that the enterprise's underlying response can be described by the following equation:

Financing Obstacle $_{\mathrm{i}, \mathrm{k}}=\alpha+\beta$ Firm Characteristics $_{\mathrm{i}, \mathrm{k}}+\gamma$ Country $_{\mathrm{k}}+\varepsilon_{\mathrm{i}, \mathrm{k}}$,

where financing obstacle is either the general financing obstacle or one of the specific obstacles mentioned above, as reported by firm i in country $\mathrm{k}$, and firm characteristics is a vector of firm attributes. These attributes include the log of age, firm size (log of sales or size dummies), sectoral dummy variables, and dummy variables for government-owned firms, foreign-owned firms, multinational enterprises, listed firms, and business group firms. Country is a vector of country dummies that allow us to control for unobserved country-specific factors that might drive firms' responses. 
Given that financing obstacle is a polychotomous dependent variable with a natural order, we use the ordered probit model to estimate regression (1). We assume that the disturbance parameter $\varepsilon$ has normal distribution and use standard maximum likelihood estimation. ${ }^{8}$ Since omitted country characteristics might cause error terms to be correlated for firms within countries, we allow for clustered error terms.

In a second step, we explore whether financial, institutional and economic development helps alleviate financing obstacles. We therefore replace the country dummies with the country-level variables described above.

\section{Which firms report financing obstacles?}

The regressions in columns 1 and 2 of Table III indicate that the size, age and foreign ownership are the most robust predictors of financing obstacles. Since we include country and sectoral dummies in all regressions, we control for country- and sector-specific characteristics that might influence firms' responses in the survey. We present results using both the log of sales and dummy variables for small and medium firms as indicators of firm size. Both the log of sales and the dummy variables for small and medium enterprises enter significantly even when controlling for other firm characteristics that are conjectured to determine financing obstacles. Small firms report significantly higher financing obstacles than medium firms, and both report higher financing obstacles than large firms. ${ }^{9}$ Reported financing obstacles decrease in the age of the enterprise. Foreign-owned firms report significantly lower financing obstacles, even when controlling for other firm

\footnotetext{
${ }^{8}$ Alternatively, we can assume a logistic function for the distribution of $\varepsilon$, resulting in the application of the logit model. However, it is difficult to justify the preference of one over the other, and in reality, the two models seem to give very similar results. See Greene (1997).

${ }^{9}$ We test whether the coefficients of small and medium firms in column 2 in Table III are significantly different from each other. The null hypothesis of no difference between the coefficients is rejected at the $10 \%$ level, suggesting that there is a significant difference between the coefficients of small and medium firms in column 2 .
} 
characteristics. While firms that are not listed, are part of a company group or are multinational enterprises also report lower financing obstacles, the coefficients are not significant. We also find that government-owned firms report higher financing obstacles; this result is only significant at the $10 \%$ level and in only one specification, however. Finally, we note that manufacturing, agricultural and construction firms report larger financing obstacles.

The regressions in columns 3-6 of Table III show significant differences between firms in developed and developing countries. The regressions in columns 3 and 4 use a sample restricted to high-income countries, while the regressions in columns 5 and 6 use a sample restricted to middle- and low-income countries. In developed economies, size seems to be less important in predicting firms' financing obstacles, while age seems to be a robust predictor; sales enters significantly only at the $10 \%$ level and neither of the two size dummies enters significantly, while age enters significantly at the $1 \%$ level. There is weak evidence that foreign-owned and listed firms report lower financing obstacles, both variables enter negatively and significantly at the 5\%-level in column 3 and significantly at the $10 \%$ level in column 4 . For firms in developing countries size is a robust predictor of financing obstacles, while age is not. Foreign-owned firms in developing countries face lower financing obstacles, while there is weak evidence (10\%) that government-owned firms face higher financing obstacles.

Table IV shows the economic significance of firm characteristics for their financing obstacles. We report the estimated probability that a firm describes financing as a major obstacle depending on its characteristics. Specifically, we set all variables at their actual 
value, except for the firm characteristic of interest. ${ }^{10}$ In the case of dummy variables we first report the estimated probability for firms for which the dummy takes on the value one and then the estimated probability for firms for which the dummy takes on the value zero. In the case of continuous variables, such as sales and age, we compare firms at the $25^{\text {th }}$ and the $75^{\text {th }}$ percentile. In the overall sample and the developing country sample, foreign ownership and size (as measured by sales) can each explain more than a 10 percentage point difference in the probability that a firm describes financing as a major obstacle; this seems substantial given that $36 \%$ of all firms in the sample rate financing as a major obstacle. Considering the size dummies instead of the log of sales still yields substantial differences between small and large firms, of around 6 to 7 percentage points. ${ }^{11}$ The differences are significantly smaller for developed countries. Age, on the other hand, seems to be the economically most important predictor of financing obstacles in developed economies; moving from the $25^{\text {th }}$ to the $75^{\text {th }}$ percentile predicts at least 5.5 percentage point decrease in the probability that a firm will describe financing as a major obstacle.

Table V confirms the findings that larger, older and foreign-owned firms report lower obstacles. Here we report the results for regressions of specific financing obstacles on firm characteristics. As before we control for country and sectoral dummies, although we do not report them. Here, we only report results using size dummies as size indicators; estimations using the log of sales yield similar results and are available on request. The small firm dummy enters positively and significantly in most regressions, with the exception of access to non-bank finance, export finance and leasing finance. Medium-sized firms report higher obstacles than large firms due to collateral requirements, paperwork

\footnotetext{
${ }^{10}$ Due to the non-linear nature of the estimation, we cannot interpret the regression coefficients as marginal effects.

${ }^{11}$ This is of course smaller than the effects reported in section 3, since here we control for other firm characteristics.
} 
$(10 \%)$, the need for special connection, and credit information. Older firms seem to face fewer obstacles in most areas, but not all. Specifically, age does not predict the degree of obstacles of high interest rates, paperwork and bureaucracy, banks' lack of money and corrupt bank officials. As in Table III, foreign firms report significantly lower obstacles in all sub-categories, while multinational enterprises do not seem to face lower obstacles, except when it comes to access to export finance and inadequate credit information (10\%), where they actually report higher obstacles. Interestingly, while we did not find a significant relation between the general financing obstacle and the fact that a firm is listed or not, when controlling for other firm characteristics, we do find that listed firms report facing significantly less obstacles when it comes to collateral requirements $(10 \%)$ and corruption of bank officials. Surprisingly, listed firms report higher obstacles in their access to non-bank equity and interest rates (10\%). Finally, firms that belong to company groups report facing higher obstacles due to corruption of bank officials and paperwork and bureaucracy $(10 \%)$.

Overall, the results in Tables III, IV and V consistently point to the young, small and domestically owned firms as facing higher obstacles than other firms. These results are consistent with some of the findings in the financing constraints literature. For example, using age as a criterion for grouping firms, both Devereux and Schiantarelli (1990) and Oliner and Rudebusch (1992) find that younger firms have higher investment-cash flow sensitivity, suggesting these firms face higher financing constraints. However, using size as attribute has led to mixed results. For example, Oliner and Rudebusch (1992) do not find significantly different investment-cash flow sensitivities for small and large firms, and Devereux and Schiantarelli (1990) even find that large firms have higher investment-cash flow sensitivities than small firms. Our result that domestic firms face higher obstacles than 
foreign firms is consistent with Harrison and McMillan (2003) who find that investmentcash flow sensitivity is higher for domestic firms than for foreign firms.

While Hoshi, Kashyap and Scharfstein (1991) and Shin and Park (1999) find lower investment-cash flow sensitivities for firms that belong to a business group, suggesting these firms face lower financing constraints, we do not find that firms that belong to a business group report lower financing obstacles. We also do not find that being listed affects the level of financing obstacles, although Oliner and Rudebusch (1992) have used listing as a criteria for grouping firms and have found that listed firms have lower investment-cash flow sensitivities, suggesting these firms face lower financing constraints. We note, however, that the fact that our sample includes only few listed firms and firms that belong to a business group, might bias our results toward insignificant coefficients on these two firm characteristics. Finally, we do not find that being a multinational or being state-owned significantly affects the level of financing obstacles reported, although Harrison and McMillan (2003) find that multinational and state-owned firms were less financially constrained than other domestic enterprises as measured by investment-cash flow sensitivities.

Our findings indicate that sorting firms according to their size, age and ownership structure (foreign versus domestic ownership) in order to test the effect of financing obstacles leads to reasonable classifications. Classification criteria such as being listed, being a multinational enterprise or belonging to a business group might be misleading, since they might represent spurious correlations. This also suggests that classification criteria based on size, age, and ownership are most useful in testing the presence of financing constraints and identifying financially constrained firms. 


\section{Firms' Financing Obstacles and Country Characteristics}

So far we have considered firm-level characteristics and their relation with financing obstacles. As described in section 2, previous research has shown that financial and legal system development alleviates financing obstacles. We therefore assess whether variation in firms' financing obstacles can be explained by cross-country variation in (i) financial intermediary development, (ii) stock market development, and (iii) legal system efficiency. Since financial development, however, is highly correlated with economic and institutional development, we include both GDP per capita and a summary indicator of institutional development, which is broader than legal system efficiency. Including country-level variables not only allows for testing the effect of specific country characteristics on firms' financing obstacles, but also constitutes a robustness test for the firm-level regressions that only controlled for country-specific effects, but not countryspecific variables.

The Table VI results indicate that firms in countries with higher levels of (i) financial intermediary development, (ii) stock market development, (iii) legal system efficiency, (iv) GDP per capita and (v) institutional development report lower financing obstacles. Private credit, law and order, and institutional development enter negatively and significantly at the $1 \%$ level, while value traded enters negatively and significantly at the $5 \%$ level and GDP per capita negatively and significantly at the $10 \%$ level. When we include the five variables simultaneously, however, only institutional development enters negatively and significantly at the $1 \%$ level; value traded enters negatively and significantly at the $10 \%$ level. Since these results might be driven by the high correlation between the country variables and thus multicollinearity, we tried different combinations of the country characteristics; only institutional development enters significantly at the $1 \%$ 
level when controlling for other country characteristics. The results also hold when we use sales as the size indicator instead of the size dummies. ${ }^{12}$

The effect of institutional development is not only statistically, but also economically significant. According to the estimates (column 5), firms in Uruguay $\left(75^{\text {th }}\right.$ percentile of institutional development) face a $12 \%$ point lower probability of rating financing as a major obstacle than in Kyrgyz Republic $\left(25^{\text {th }}\right.$ percentile). Overall, these results seem to indicate that broad institutional development is important in alleviating firms' financing obstacles. While firms in financially and economically more developed countries face lower financing obstacles, the underlying institutions driving both economic and financial development seem to be the most important country characteristic explaining firms' financing obstacles. These findings also suggest that it is hard to distinguish the effects of financial, legal and economic development from the underlying institutional development.

When we include country-level variables, the firm characteristics we previously found to be significant in predicting firms' financing obstacles continue to enter significantly; larger, older and foreign-owned firms report lower obstacles. Unlike in the Table III regressions, multinational also enters negatively and significantly in all but one regression, indicating that multinational companies face lower financing obstacles; this effect, however, is due to the smaller sample, which we utilize in Table VI compared to Table III. ${ }^{13}$

\footnotetext{
${ }^{12} \mathrm{We}$ also ran regressions controlling for growth, inflation and their respective volatility. The significance of institutional development is not affected, while none of the macroeconomic variables enters significantly.

${ }^{13}$ When we re-run the Table III regressions with the sample limited to countries for which we have the country-level variables, multinational enters significantly.
} 


\section{Conclusions}

In this paper we explore the firm characteristics that predict firms' financing obstacles. We find that age, size and ownership predict financing obstacles best; younger, smaller and domestic firms report higher obstacles. Categorizing firms by their age, size and ownership is therefore most useful when considering the effect of financial and institutional development on firms' financing obstacles.

Our results show that some of the a priori classifications used in the literature to distinguish between financially constrained and unconstrained firms are more useful than others. Importantly, some of these a priori groupings appear to be misleading as they represent spurious correlations with other firm attributes. Given the limitations of existing methods to estimate financing constraints directly from firm-level data, our results based on survey data are an important contribution in improving our understanding of which firm attributes best predict firms' financing obstacles.

We also consider the effect of country characteristics on firms' financing obstacles. We find that firms in countries with higher levels of financial intermediary development, more liquid stock markets, more efficient legal systems and higher GDP per capita report lower financing obstacles. The most important country characteristic explaining crosscountry variation in firms' financing obstacles, however, seems to be overall institutional development. 


\section{References}

Abel, A. (1980), "Empirical Investment Equations: An Integrative Framework", in: K. Brunner and A. Meltzer (eds.), On the State of Macroeconomics, CarnegieRochester Conference Series 12, pp. 39-93.

Abel, A. and O. Blanchard (1986), "The Present Value of Profits and Cyclical Movements in Investment", Econometrica 54, 249-274.

Almeida, H. and M. Campello (2001), "Financial Constraints and Investment-Cash Flow Sensitivities: New Research Directions", mimeo, New York University.

Batra, G., Kaufmann, D and A. Stone (2002): Voices of the Firms 2000: Investment Climate and Governance Findings of the World Business Environment Survey (WBES), World Bank mimeo.

Beck, T., A. Demirgüç-Kunt, and V. Maksimovic (2004), "Financial and Legal Constraints to Firm Growth: Does Size Matter?", Journal of Finance, forthcoming.

Beck, T., R. Levine, and N. Loayza (2000), "Finance and the Sources of Growth", Journal of Financial Economics 58, 261-300.

Beck, T. and R. Levine (2003), "Stock Markets, Banks and Growth: Panel Evidence", Journal of Banking and Finance, forthcoming.

Blundell, R., S. R. Bond and C. Meghir (1996), "Econometric Models of Company Investment", in: Matyas, L. and P. Sevestre (ed.), The Econometrics of Panel Data: A Handbook of the Theory with Applications, Advanced Studies in Theoretical and Applied Econometrics, Volume 33, Kluwer Academic Publishers.

Bond, S. R. and C. Meghir (1994), "Dynamic Investment models and the Firm's Financial Policy", Review of Economic Studies 61, 197-222. 
Bond, S. and J. Van Reenen (1999), "Microeconomic Models of Investment and Employment”, Forthcoming In: J. J. Heckman and E. E. Leamer (eds.), Handbook of Econometrics, Volume 5, Elsevier Science, North-Holland, Amsterdam.

Demirgüç-Kunt, A. and V. Maksimovic (1998), "Law, Finance, and Firm Growth", Journal of Finance 53, 2107-2137.

Devereux, M. and F. Schiantarelli (1990), "Investment, Financial Factors and Cash Flow from U.K. Panel Data”, in: G. Hubbard (ed.), Information, Capital Markets and Investment, Chicago, IL: University of Chicago Press.

Fazzari, S., G. Hubbard and B. Petersen (1988), "Financing Constraints and Corporate Investment", Brookings Papers on Economic Activity 1, 141-95.

(2000), "Investment-Cash Flow Sensitivities are Useful: A Comment on Kaplan and Zingales", Quarterly Journal of Economics $115,695-705$.

Gelos, G. and A. Werner (2002), "Financial Liberalization, Credit Constraints, and Collateral: Investment in the Mexican Manufacturing Sector", Journal of Development Economics 67(1), 1-27.

Gertler, Mark (1988), "Financial Structure and Aggregate Economic Activity: An Overview", Journal of Money, Credit, and Banking 20, 559-596.

Gilchrist, S. and C. Himmelberg (1995), "Evidence on the Role of Cash Flow for Investment", Journal of Monetary Economics 36, 541-572.

(1998), "Investment, Fundamentals and Finance", NBER Macroeconomics Annual: MIT Press. 
Gomes, J. F. (2001), “Financing Investment”, American Economic Review 91(5), 12631285.

Greene, W.H. (1997), Econometric Analysis, Third Edition, Upper Saddle River, New Jersey: Prentice Hall.

Harrison, A. and M. McMillan (2003), "Does Direct Foreign Investment Affect Domestic Firm Credit Constraints?”, Journal of International Economics 61(1), 73-100.

Hayashi, F. (1982), “Tobin's Marginal $q$ and Average $q$ : A Neoclassical Interpretation”, Econometrica 50(1), 213-224.

Hoshi, T., A. Kashyap, and D. Scharfstein (1991), "Corporate Structure, Liquidity and Investment: Evidence from Japanese Industrial Groups”, Quarterly Journal of Economics 106(1), 33-60.

Hubbard, G. (1998), “Capital Market Imperfections and Investment”, Journal of Economic Literature 36(3), 193-225.

Kaplan, S. and L. Zingales (1997), “Do Investment-Cash Flow Sensitivities Provide Useful Measures of Financing Constraints?", Quarterly Journal of Economics 112, $169-215$.

(2000), "Investment-Cash Flow Sensitivities Are Not Valid Measures of Financing Constraints", Quarterly Journal of Economics 115, 707712.

Kaufman, D., Kraay, A. and M. Mastruzzi. (2003). “Governance Matters III: Governance Indicators for 1996-2002”. World Bank Policy Research Working Paper 2196.

Laeven, L. (2003), “Does Financial Liberalization Reduce Financing Constraints?”, 
Financial Management 32(1), 5-34.

Lamont, O. (1997), “Cash Flow and Investment: Evidence from Internal Capital Markets", Journal of Finance 52(1), 83-109.

Love, I. (2003), "Financial Development and Financing Constraints: International Evidence from the Structural Investment Model", Review of Financial Studies 16(3), 765-791.

Oliner, S. D. and G. D. Rudebusch (1992), "Sources of the Financing Hierarchy for Business Investment", Review of Economics and Statistics 74(2), 643-54.

Povel, P. and M. Raith (2002), "Optimal Investment Under Financial Constraints: the Roles of Internal Funds and Asymmetric Information", mimeo, Universities of Minnesota and Rochester, July 2002.

Sembenelli, A. and F. Schiantarelli (1996), "Form of Ownership and Financial Constraints", Working Paper No. 1629, World Bank.

Schiantarelli, F. (1995), "Financial Constraints and Investment: A Critical Review of Methodological Issues and International Evidence", in: J. Peek and E. Rosengren (eds.), Is Bank Lending Important for the Transmission of Monetary Policy?, Boston, MA: Federal Reserve Bank of Boston.

Schiffer, M. and B. Weder (2001), "Firm Size and the Business Environment: Worldwide Survey Results", Discussion Paper No. 43, International Finance Corporation, Washington, D.C., August 2001.

Shin, H.-H. and Y. S. Park (1999), "Financing Constraints and Internal Capital Markets: Evidence from Korean 'Chaebols”, Journal of Corporate Finance 5(2), 169-191.

Tobin, J. (1969), “A General Equilibrium Approach to Monetary Theory”, Journal of 
Money, Credit, and Banking 1(1), 15-29.

Whited, T. (1992), "Debt, Liquidity Constraints, and Corporate Investment: Evidence from Panel Data", Journal of Finance 47(4), 1425-60. 


\section{Table I \\ Financing Obstacles Across Different Groups of Firms}

Small firms employ 5 to 50 employees, medium firms 51 to 500 employees and large firms over 500 employees. Listed firms are firms that are listed on a stock exchange. Group-owned firms are firms controlled by a company group. Multinational firms are firms that have holdings or operations in other countries.

Foreign-owned firms are firms with foreign ownership. Government-owned firms are firms with government ownership. The general financing obstacle is a survey response to the question: How problematic is financing for the operation and growth of your business? Answers vary between 1 (no obstacle), 2 (minor obstacle), 3 (moderate obstacle), and 4 (major obstacle).

\begin{tabular}{lrr}
\hline Variable & Number of observations & General Financing Obstacle \\
\hline Small & 3,759 & 2.87 \\
Medium & 3,726 & 2.85 \\
Large & 1,726 & 2.59 \\
& & \\
Manufacturing & 3,068 & 2.81 \\
Services & 3,684 & 2.69 \\
Agriculture & 605 & 3.25 \\
Construction & 784 & 2.99 \\
Other & 280 & 2.78 \\
& & \\
Listed & 883 & 2.71 \\
Not listed & 7,559 & 2.80 \\
& & \\
Group-owned & 557 & 2.62 \\
Not group-owned & 8,177 & 2.82 \\
& & \\
Multinational & 1,598 & 2.48 \\
National & 7,346 & 2.88 \\
Foreign-owned & & \\
Domestic-owned & 1,616 & 2.43 \\
Government-owned & 7,332 & 2.89 \\
Privately-owned & & \\
& 1,115 & 2.96 \\
\hline
\end{tabular}


Table II

Summary Statistics and Correlations

The general financing obstacle is a survey response to the question: How problematic is financing for the operation and growth of your business? Answers vary between 1 (no obstacle), 2 (minor obstacle), 3 (moderate obstacle), and 4 (major obstacle). The other financing obstacles are survey responses to questions concerning specific financing obstacles, as specified in the questionnaire. Age is defined as the log of the years since establishment of the firm. Small firms employ 5 to 50 employees, medium firms 51 to 500 employees and large firms over 500 employees. Sales is the log of total firm sales. Listed firms are firms that are listed on a stock exchange. Group indicates firms controlled by a company group. Multinational firms are firms that have holdings or operations in other countries. Foreign indicates firms are firms with foreign ownership. Government indicates firms with government ownership. Manufacturing, Service, Agriculture, Construction and Other are sectoral dummy variables. Private Credit is the log of the claims on the private sector by financial institutions as share of GDP. Value Traded is the log of total value traded on stock exchanges as share of GDP. Law and Order is an indicator of the efficiency of a country's legal system. GDP per capita is in real terms and averaged over the period 1995-99. Institutional Development is a summary indicator of institutional development.

\section{Panel A:}

\begin{tabular}{|c|c|c|c|c|c|c|}
\hline Variable & Mean & Median & $\begin{array}{r}\text { Standard } \\
\text { Deviation }\end{array}$ & Maximum & Minimum & $\overline{\text { Observations }}$ \\
\hline General financing obstacle & 2.81 & 3 & 1.12 & 4 & 1 & $\overline{9,229}$ \\
\hline High interest rates & 3.22 & 4 & 1.04 & 4 & 1 & 9,357 \\
\hline Collateral requirements & 2.50 & 3 & 1.17 & 4 & 1 & 8,964 \\
\hline Access to long-term loans & 2.63 & 3 & 1.26 & 4 & 1 & 7,024 \\
\hline Bank paperwork/bureaucracy & 2.49 & 2 & 1.08 & 4 & 1 & 9,127 \\
\hline Need special connection & 2.19 & 2 & 1.08 & 4 & 1 & 8.913 \\
\hline Banks lack money to lend & 2.11 & 2 & 1.20 & 4 & 1 & 8,645 \\
\hline Access to foreign banks & 2.06 & 2 & 1.18 & 4 & 1 & 7,658 \\
\hline Access to non-bank equity & 2.10 & 2 & 1.15 & 4 & 1 & 7,559 \\
\hline Access to export finance & 2.08 & 2 & 1.18 & 4 & 1 & 6,711 \\
\hline Access to leasing finance & 2.07 & 2 & 1.14 & 4 & 1 & 7,637 \\
\hline Inadequate credit/financial information & 2.27 & 2 & 1.13 & 4 & 1 & 7,982 \\
\hline Corruption of bank officials & 1.77 & 1 & 1.05 & 4 & 1 & 8,075 \\
\hline Age & 2.34 & 2.20 & 1.10 & 6.40 & 0 & 7,933 \\
\hline Small & 0.40 & 0 & 0.49 & 1 & 0 & 10,007 \\
\hline Medium & 0.40 & 0 & 0.49 & 1 & 0 & 10,007 \\
\hline Large & 0.19 & 0 & 0.39 & 1 & 0 & 10,007 \\
\hline Sales & 9.87 & 12.21 & 8.00 & 25.33 & -2.12 & 9,034 \\
\hline Listed & 0.10 & 0 & 0.31 & 1 & 0 & 9,160 \\
\hline Group & 0.07 & 0 & 0.25 & 1 & 0 & 9,444 \\
\hline Foreign & 0.19 & 0 & 0.39 & 1 & 0 & 9,673 \\
\hline Government & 0.12 & 0 & 0.33 & 1 & 0 & 9,645 \\
\hline Multinational & 0.18 & 0 & 0.39 & 1 & 0 & 9,668 \\
\hline Manufacturing & 0.36 & 0 & 0.48 & 1 & 0 & 9,141 \\
\hline Services & 0.43 & 0 & 0.50 & 1 & 0 & 9,141 \\
\hline Other & 0.04 & 0 & 0.19 & 1 & 0 & 9,141 \\
\hline Agriculture & 0.07 & 0 & 0.26 & 1 & 0 & 9,141 \\
\hline Construction & 0.10 & 0 & 0.29 & 1 & 0 & 9,141 \\
\hline Private Credit & 0.36 & 0.23 & 0.36 & 0.01 & 1.63 & 74 \\
\hline Value Traded & 0.09 & 0.01 & 0.19 & 0.00 & 1.06 & 79 \\
\hline Law and Order & 3.77 & 3.63 & 1.21 & 1.50 & 6 & 63 \\
\hline GDP per capita & 4,643 & 1,709 & 7,487 & 109 & 30.794 & 80 \\
\hline Institutional Development & 0.05 & -0.12 & 0.67 & 1.53 & -1.14 & 80 \\
\hline
\end{tabular}


Panel B: Correlation Matrix of Variables

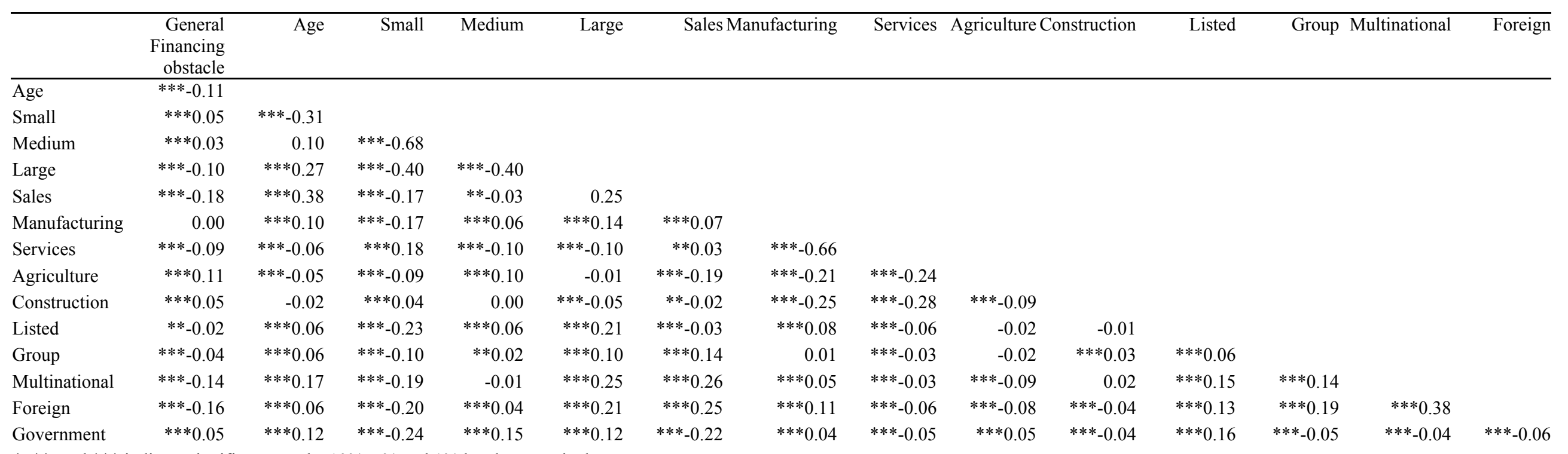




\section{Table III}

\section{Financing Obstacles and Firm Characteristics}

The regression estimated is: General Financing Obstacle $=\alpha+\beta_{1}$ Manufacturing $+\beta_{2}$ Services $+\beta_{3}$ Agriculture $+\beta_{4}$ Construction $+\beta_{5}$ Size $+\beta_{6}$ Multinational $+\beta_{7}$ Government $+\beta_{8}$ Foreign $+\beta_{9}$ Group $+\beta_{10}$ Listed $+\beta_{11}$ Age $+\varepsilon$. General Financing Obstacle is the response to the question "How problematic is financing for the operation and growth of your business?" Answers vary between 1 (no obstacle), 2 (minor obstacle), 3 (moderate obstacle), and 4 (major obstacle). Age is defined as the log of the years since establishment of the firm. Size is either the log of total firm sales or two dummy variables indicating small and medium firms. Small firms employ 5 to 50 employees, medium firms 51 to 500 employees and large firms over 500 employees. Listed firms are firms that are listed on a stock exchange. Group indicates firms controlled by a company group. Multinational firms are firms that have holdings or operations in other countries. Foreign indicates firms are firms with foreign ownership. Government indicates firms with government ownership. All regressions also include country dummies. The regressions are estimated with ordered probit. Z-statistics are reported in parentheses and *, **, *** indicate significance at the $10 \%, 5 \%$ and $1 \%$ level, respectively. Regressions in columns 1 and 2 use the whole sample; regressions in columns 3 and 4 a sample restricted to firms in high-income countries; and regressions in columns 5 and 6 a sample restricted to firms in middle- and low-income countries. Countries are classified as high-, middle- or lowincome according to the World Development Indicators.

\begin{tabular}{lllllll}
\hline & $(1)$ & $(2)$ & $(3)$ & $(4)$ & $(5)$ & $(6)$ \\
\hline Manufacturing & 0.236 & 0.290 & 0.275 & 0.389 & 0.237 & 0.268 \\
& $(1.98)^{* *}$ & $(2.34)^{* *}$ & $(6.36)^{* * *}$ & $(3.63)^{* * *}$ & $(1.26)$ & $(1.47)$ \\
Services & 0.084 & 0.117 & 0.148 & 0.24 & 0.084 & 0.093 \\
& $(0.66)$ & $(0.90)$ & $(2.25)^{* *}$ & $(2.20)^{* *}$ & $(0.42)$ & $(0.49)$ \\
Agriculture & 0.523 & 0.595 & 0.262 & 0.332 & 0.533 & 0.581 \\
& $(3.12)^{* * *}$ & $(3.42)^{* * *}$ & $(0.58)$ & $(0.69)$ & $(2.33)^{* *}$ & $(2.56)^{* *}$ \\
Construction & 0.398 & 0.425 & 0.306 & 0.391 & 0.425 & 0.428 \\
& $(3.07)^{* * *}$ & $(3.20)^{* * *}$ & $(3.16)^{* * *}$ & $(3.14)^{* * *}$ & $(2.15)^{* *}$ & $(2.24)^{* *}$ \\
Sales & -0.021 & & -0.025 & & -0.019 & \\
& $(3.10)^{* * *}$ & & $(1.85)^{*}$ & & $(2.58)^{* * *}$ & \\
Multinational & -0.068 & -0.056 & -0.027 & 0.015 & -0.070 & -0.062 \\
& $(1.31)$ & $(1.08)$ & $(0.30)$ & $(0.14)$ & $(1.15)$ & $(1.05)$ \\
Government & 0.094 & 0.112 & -0.068 & -0.064 & 0.117 & 0.139 \\
& $(1.45)$ & $(1.73)^{*}$ & $(0.45)$ & $(0.47)$ & $(1.68)^{*}$ & $(1.93)^{*}$ \\
Foreign & -0.358 & -0.343 & -0.230 & -0.190 & -0.379 & -0.369 \\
& $(7.33)^{* * *}$ & $(6.94)^{* * *}$ & $(2.04)^{* *}$ & $(1.91)^{*}$ & $(6.90)^{* * *}$ & $(6.49)^{* * *}$ \\
Group & -0.038 & -0.017 & -0.183 & -0.200 & -0.008 & 0.025 \\
& $(0.50)$ & $(0.23)$ & $(1.18)$ & $(1.53)$ & $(0.09)$ & $(0.30)$ \\
Listed & 0.028 & 0.056 & -0.174 & -0.126 & -0.063 & 0.088 \\
& $(0.49)$ & $(1.06)$ & $(1.99)^{* *}$ & $(1.79)^{*}$ & $(1.03)$ & $(1.48)$ \\
Age & -0.056 & -0.043 & -0.177 & -0.171 & -0.027 & -0.010 \\
& $(2.34)^{* *}$ & $(1.79)^{*}$ & $(3.24)^{* * *}$ & $(3.21)^{* * *}$ & $(1.05)$ & $(0.41)$ \\
Small & & 0.229 & & 0.264 & & 0.228 \\
& & $(3.40)^{* * *}$ & & $(1.33)$ & & $(3.21)^{* * *}$ \\
Medium & & 0.140 & & 0.114 & & 0.149 \\
& & $(2.98)^{* * *}$ & & $(0.94)$ & & $(2.85)^{* * *}$ \\
Pseudo $\mathrm{R}^{2}$ & & 0.076 & 0.046 & 0.050 & 0.058 & 0.059 \\
Observations & & & 927 & 971 & 5129 & 5208 \\
\hline
\end{tabular}




\section{Table IV \\ Financing Obstacles and Firm Characteristics - Quantifying the Effect}

Based on the regressions of Table III, estimated probabilities of rating financing as major obstacle to the operation and growth of the enterprises (Financing Obstacle $=4$ ) are presented. Estimated probabilities are calculated for each enterprise setting all variables at its actual value, except for the firm characteristic of interest. In the case of dummies, the first line reports the probability if the dummy variable takes on the value one, while the second row reports the probability if the dummy variable takes on the value one. In the case of Age and Sales, the first and second rows show the probability at the $25^{\text {th }}$ and $75^{\text {th }}$ percentile of the respective variable. The third row reports in bold the difference between the first and second row. In the case of size dummies only the probabilities for the respective size dummies are reported. Age is defined as the log of the years since establishment of the firm. Sales is the log of total firm sales. Listed firms are firms that are listed on a stock exchange. Group indicates firms controlled by a company group. Multinational firms are firms that have holdings or operations in other countries. Foreign indicates firms are firms with foreign ownership. Government indicates firms with government ownership. Small firms employ 5 to 50 employees, medium firms 51 to 500 employees and large firms over 500 employees.

\begin{tabular}{|c|c|c|c|c|c|c|}
\hline & (1) & (2) & (3) & (4) & (5) & (6) \\
\hline \multirow[t]{3}{*}{ Sales } & 0.427 & & 0.209 & & 0.421 & \\
\hline & 0.315 & & 0.166 & & 0.320 & \\
\hline & 0.112 & & 0.043 & & 0.101 & \\
\hline \multirow[t]{3}{*}{ Multinational } & 0.374 & 0.372 & 0.253 & 0.175 & 0.373 & 0.388 \\
\hline & 0.351 & 0.353 & 0.250 & 0.179 & 0.350 & 0.367 \\
\hline & 0.023 & 0.019 & 0.003 & -0.004 & 0.023 & 0.021 \\
\hline \multirow[t]{3}{*}{ Government } & 0.369 & 0.366 & 0.253 & 0.176 & 0.367 & 0.382 \\
\hline & 0.401 & 0.404 & 0.233 & 0.161 & 0.407 & 0.431 \\
\hline & -0.032 & -0.038 & 0.020 & 0.015 & -0.04 & -0.049 \\
\hline \multirow[t]{3}{*}{ Foreign } & 0.390 & 0.388 & 0.262 & 0.183 & 0.390 & 0.407 \\
\hline & 0.274 & 0.276 & 0.197 & 0.138 & 0.268 & 0.282 \\
\hline & 0.116 & 0.112 & 0.065 & 0.045 & 0.122 & 0.125 \\
\hline \multirow[t]{3}{*}{ Group } & 0.371 & 0.369 & 0.253 & 0.177 & 0.370 & 0.385 \\
\hline & 0.358 & 0.363 & 0.202 & 0.131 & 0.367 & 0.394 \\
\hline & 0.013 & 0.006 & 0.051 & 0.046 & 0.003 & -0.009 \\
\hline \multirow[t]{3}{*}{ Listed } & 0.376 & 0.372 & 0.258 & 0.175 & 0.375 & 0.388 \\
\hline & 0.385 & 0.391 & 0.209 & 0.146 & 0.397 & 0.420 \\
\hline & -0.009 & -0.019 & 0.049 & 0.029 & -0.022 & -0.032 \\
\hline \multirow[t]{3}{*}{ Age } & 0.356 & 0.359 & 0.240 & 0.168 & 0.352 & 0.367 \\
\hline & 0.326 & 0.336 & 0.169 & 0.113 & 0.337 & 0.361 \\
\hline & 0.03 & 0.023 & 0.071 & 0.055 & 0.015 & 0.006 \\
\hline Small & & 0.393 & & 0.199 & & 0.409 \\
\hline Medium & & 0.363 & & 0.161 & & 0.381 \\
\hline Large & & 0.317 & & 0.135 & & 0.330 \\
\hline
\end{tabular}


Table V

\section{Specific Financing Obstacles and Firm Characteristics}

The regression estimated is: Financing Obstacle $=\alpha+\beta_{1}$ Manufacturing $+\beta_{2}$ Services $+\beta_{3}$ Agriculture $+\beta_{4}$ Construction $+\beta_{5}$ Size $+\beta_{6}$ Multinational $+\beta_{7}$ Government $+\beta_{8}$ Foreign $+\beta_{9}$ Group $+\beta_{10}$ Listed $+\beta_{11}$ Age $+\varepsilon$. Financing Obstacle is the response to specific issues in the financial sector that constrain the growth and operation of firms. Answers vary between 1 (no obstacle), 2 (minor obstacle), 3 (moderate obstacle), and 4 (major obstacle). Age is defined as the log of the years since establishment of the firm. Size is a vector of size dummies; Small firms employ 5 to 50 employees, medium firms 51 to 500 employees and large firms over 500 employees. Listed firms are firms that are listed on a stock exchange. Group indicates firms controlled by a company group. Multinational firms are firms that have holdings or operations in other countries. Foreign indicates firms are firms with foreign ownership. Government indicates firms with government ownership. All regressions also include country dummies. The regressions are estimated with ordered probit. Z-statistics are reported in parentheses and *, $* *, * * *$ indicate significance at the $10 \%, 5 \%$ and $1 \%$ level, respectively.

\begin{tabular}{|c|c|c|c|c|c|c|c|c|c|c|c|c|}
\hline & (1) & (2) & (3) & (4) & (5) & (6) & (7) & (8) & (9) & (10) & (11) & (12) \\
\hline & $\begin{array}{l}\text { High interes } \\
\text { rates }\end{array}$ & $\begin{array}{l}\text { Collateral } \\
\text { requirements }\end{array}$ & $\begin{array}{l}\text { Access to } \\
\text { long-term } \\
\text { loans }\end{array}$ & $\begin{array}{l}\text { Bank } \\
\text { paperwork }\end{array}$ & $\begin{array}{l}\text { Need special } \\
\text { connection }\end{array}$ & $\begin{array}{l}1 \text { Bank lack } \\
\text { money to } \\
\text { lend }\end{array}$ & $\begin{array}{l}\text { Access to } \\
\text { foreign } \\
\text { banks }\end{array}$ & $\begin{array}{l}\text { Access to } \\
\text { non-bank } \\
\text { equity }\end{array}$ & $\begin{array}{l}\text { Access to } \\
\text { export } \\
\text { finance }\end{array}$ & $\begin{array}{l}\text { Access to } \\
\text { leasing } \\
\text { finance }\end{array}$ & $\begin{array}{l}\text { Inadequate } \\
\text { credit } \\
\text { information }\end{array}$ & $\begin{array}{l}\text { Corruption } \\
\text { of bank } \\
\text { officials }\end{array}$ \\
\hline \multirow[t]{2}{*}{$\overline{\text { Age }}$} & -0.006 & -0.062 & -0.042 & -0.025 & -0.036 & 0.006 & -0.036 & -0.037 & -0.035 & -0.048 & -0.035 & -0.009 \\
\hline & $(0.30)$ & $(3.21)^{* * *}$ & $(2.02)^{* *}$ & $(1.53)$ & $(2.29)^{* *}$ & $(0.29)$ & $(1.70)^{*}$ & $(2.12)^{* *}$ & $(1.72)^{*}$ & $(2.23)^{* *}$ & $(1.73)^{*}$ & $(0.46)$ \\
\hline \multirow[t]{2}{*}{ Small } & 0.133 & 0.246 & 0.150 & 0.197 & 0.232 & 0.113 & 0.166 & 0.058 & 0.051 & 0.107 & 0.169 & 0.228 \\
\hline & $(2.03)^{* *}$ & $(4.19)^{* * *}$ & $(2.99)^{* * *}$ & $(3.29)^{* * *}$ & $(4.44)^{* * *}$ & $(2.04)^{* *}$ & $(2.44)^{* *}$ & (1.14) & $(0.72)$ & $(1.55)$ & $(3.26)^{* * *}$ & $(3.84)^{* * *}$ \\
\hline \multirow[t]{2}{*}{ Medium } & 0.081 & 0.149 & 0.027 & 0.091 & 0.135 & 0.068 & 0.091 & 0.031 & 0.081 & 0.065 & 0.121 & 0.037 \\
\hline & $(1.46)$ & $(2.88) * * *$ & $(0.58)$ & $(1.75)^{*}$ & $(2.95)^{* * *}$ & $(1.45)$ & $(1.44)$ & $(0.54)$ & $(1.12)$ & $(1.16)$ & $(2.62)^{* * *}$ & $(0.68)$ \\
\hline \multirow[t]{2}{*}{ Listed } & 0.095 & -0.091 & -0.035 & -0.108 & -0.089 & 0.001 & 0.067 & 0.187 & 0.071 & 0.101 & -0.065 & -0.150 \\
\hline & $(1.69)^{*}$ & $(1.74)^{*}$ & $(0.47)$ & $(1.46)$ & $(1.52)$ & $(0.02)$ & $(1.10)$ & $(3.37)^{* * *}$ & $(1.35)$ & (1.49) & (1.09) & $(1.99)^{* *}$ \\
\hline \multirow[t]{2}{*}{ Group } & -0.007 & 0.038 & -0.141 & 0.088 & 0.019 & 0.059 & 0.021 & -0.069 & 0.018 & -0.036 & 0.041 & 0.201 \\
\hline & $(0.10)$ & $(0.61)$ & $(1.62)$ & $(1.74)^{*}$ & $(0.27)$ & $(0.76)$ & $(0.28)$ & $(0.93)$ & $(0.20)$ & $(0.48)$ & $(0.62)$ & $(3.99)^{* * *}$ \\
\hline \multirow[t]{2}{*}{ Foreign } & -0.260 & -0.252 & -0.242 & -0.108 & -0.126 & -0.121 & -0.279 & -0.240 & -0.149 & -0.234 & -0.119 & -0.107 \\
\hline & $(6.61)^{* * *}$ & $(5.76)^{* * *}$ & $(4.98)^{* * *}$ & $(2.41)^{* *}$ & $(2.93)^{* * *}$ & $(2.62)^{* * *}$ & $(4.86)^{* * *}$ & $(4.78) * * *$ & $(2.71)^{* * *}$ & $(5.91)^{* * *}$ & $(2.57)^{* *}$ & $(1.99)^{* *}$ \\
\hline \multirow[t]{2}{*}{ Government } & 0.103 & -0.048 & -0.020 & -0.064 & -0.082 & 0.001 & -0.003 & -0.030 & -0.029 & -0.050 & -0.012 & -0.119 \\
\hline & $(1.60)$ & $(0.75)$ & $(0.33)$ & $(1.05)$ & $(1.31)$ & $(0.02)$ & $(0.04)$ & $(0.43)$ & $(0.46)$ & $(0.75)$ & $(0.18)$ & $(1.54)$ \\
\hline \multirow[t]{2}{*}{ Multinational } & -0.068 & 0.025 & -0.005 & -0.007 & 0.018 & 0.016 & 0.045 & 0.006 & 0.131 & 0.013 & 0.080 & 0.039 \\
\hline & $(1.61)$ & $(0.64)$ & $(0.09)$ & $(0.17)$ & $(0.49)$ & $(0.32)$ & $(0.92)$ & $(0.15)$ & $(2.62)^{* * *}$ & $(0.31)$ & $(1.80)^{*}$ & $(0.70)$ \\
\hline Pseudo $\mathrm{R}^{2}$ & 0.103 & 0.052 & 0.100 & 0.052 & 0.041 & 0.099 & 0.066 & 0.051 & 0.061 & 0.085 & 0.047 & 0.102 \\
\hline Observations & 6163 & 5833 & 5507 & 5974 & 5813 & 5579 & 4830 & 4763 & 4156 & 4866 & 5074 & 5150 \\
\hline
\end{tabular}




\section{Financing Obstacles and Country Characteristics}

The regression estimated is: General Financing Obstacle $=\alpha+\beta_{1}$ Manufacturing $+\beta_{2}$ Services $+\beta_{3}$ Agriculture $+\beta_{4}$ Construction $+\beta_{5}$ Size $+\beta_{6}$ Multinational $+\beta_{7}$ Government $+\beta_{8}$ Foreign $+\beta_{9}$ Group $+\beta_{10}$ Listed $+\beta_{11}$ Age $+\beta_{11}$ Country $+\varepsilon$. General Financing Obstacle is the response to the question "How problematic is financing for the operation and growth of your business?" Answers vary between 1 (no obstacle), 2 (minor obstacle), 3 (moderate obstacle), and 4 (major obstacle). Size is a vector of size dummies; Small firms employ 5 to 50 employees, medium firms 51 to 500 employees and large firms over 500 employees. Listed firms are firms that are listed on a stock exchange. Group indicates firms controlled by a company group. Multinational firms are firms that have holdings or operations in other countries. Foreign indicates firms are firms with foreign ownership. Government indicates firms with government ownership. Country is a vector of five variables. Private Credit is the log of the claims on the private sector by financial institutions as share of GDP. Value Traded is the log of total value traded on stock exchanges as share of GDP. Law and Order is an indicator of the efficiency of a country's legal system. Institutional Development is a composite indicator of institutional development. GDP per capita is in real terms and averaged over the period 1995-99. The regressions are estimated with ordered probit. Z-statistics are reported in parentheses and *,**,*** indicate significance at the $10 \%, 5 \%$ and $1 \%$ level, respectively.

\begin{tabular}{|c|c|c|c|c|c|c|}
\hline & (1) & (2) & (3) & (4) & (5) & (6) \\
\hline$\overline{\mathrm{Age}}$ & $\begin{array}{l}-0.084 \\
(2.94)^{* * *}\end{array}$ & $\begin{array}{l}-0.121 \\
(4.45)^{* * * *}\end{array}$ & $\begin{array}{l}-0.130 \\
(5.67)^{* * *}\end{array}$ & $\begin{array}{l}-0.062 \\
(2.53)^{* *}\end{array}$ & $\begin{array}{l}-0.033 \\
(1.18)\end{array}$ & $\begin{array}{l}-0.078 \\
(2.77) * * *\end{array}$ \\
\hline Small & $\begin{array}{l}0.183 \\
(2.40)^{* *}\end{array}$ & $\begin{array}{l}0.171 \\
(2.21)^{* *}\end{array}$ & $\begin{array}{l}0.284 \\
(3.69)^{* * *}\end{array}$ & $\begin{array}{l}0.142 \\
(1.57)\end{array}$ & $\begin{array}{l}0.186 \\
(2.15)^{* *}\end{array}$ & $\begin{array}{l}0.242 \\
(3.40)^{* * *}\end{array}$ \\
\hline Medium & $\begin{array}{l}0.118 \\
(2.24)^{* *}\end{array}$ & $\begin{array}{l}0.124 \\
(2.17)^{* *}\end{array}$ & $\begin{array}{l}0.173 \\
(2.90)^{* * *}\end{array}$ & $\begin{array}{l}0.154 \\
(2.98)^{* * *}\end{array}$ & $\begin{array}{l}0.165 \\
(3.46)^{* * *}\end{array}$ & $\begin{array}{l}0.148 \\
(2.69)^{* * *}\end{array}$ \\
\hline Listed & $\begin{array}{l}0.008 \\
(0.13)\end{array}$ & $\begin{array}{l}0.057 \\
(0.88)\end{array}$ & $\begin{array}{l}-0.060 \\
(0.76)\end{array}$ & $\begin{array}{l}0.057 \\
(0.75)\end{array}$ & $\begin{array}{l}0.046 \\
(0.72)\end{array}$ & $\begin{array}{l}-0.090 \\
(1.57)\end{array}$ \\
\hline Group & $\begin{array}{l}0.030 \\
(0.41)\end{array}$ & $\begin{array}{l}0.024 \\
(0.30)\end{array}$ & $\begin{array}{l}-0.017 \\
(0.22)\end{array}$ & $\begin{array}{l}0.002 \\
(0.03)\end{array}$ & $\begin{array}{l}0.023 \\
(0.32)\end{array}$ & $\begin{array}{l}0.023 \\
(0.27)\end{array}$ \\
\hline Foreign & $\begin{array}{l}-0.291 \\
(6.20)^{* * *}\end{array}$ & $\begin{array}{l}-0.304 \\
(6.40)^{* * *}\end{array}$ & $\begin{array}{l}-0.292 \\
(5.43)^{* * *}\end{array}$ & $\begin{array}{l}-0.355 \\
(7.30)^{* * *}\end{array}$ & $\begin{array}{l}-0.331 \\
(6.77)^{* * *}\end{array}$ & $\begin{array}{l}-0.252 \\
(4.76)^{* * *}\end{array}$ \\
\hline Government & $\begin{array}{l}0.077 \\
(0.69)\end{array}$ & $\begin{array}{l}0.070 \\
(0.66)\end{array}$ & $\begin{array}{l}0.151 \\
(1.36)\end{array}$ & $\begin{array}{l}0.125 \\
(1.44)\end{array}$ & $\begin{array}{l}0.101 \\
(1.22)\end{array}$ & $\begin{array}{l}0.058 \\
(0.58)\end{array}$ \\
\hline Multinational & $\begin{array}{l}-0.152 \\
(2.66) * * *\end{array}$ & $\begin{array}{l}-0.147 \\
(2.47)^{* *}\end{array}$ & $\begin{array}{l}-0.152 \\
(2.49)^{* *}\end{array}$ & $\begin{array}{l}-0.127 \\
(1.99)^{* *}\end{array}$ & $\begin{array}{l}-0.106 \\
(1.90)^{*}\end{array}$ & $\begin{array}{l}-0.104 \\
(1.56)\end{array}$ \\
\hline Private Credit & $\begin{array}{l}-0.142 \\
(2.71)^{* * *}\end{array}$ & & & & & $\begin{array}{l}0.108 \\
(1.42)\end{array}$ \\
\hline Value Traded & & $\begin{array}{l}-0.050 \\
(2.37)^{* *}\end{array}$ & & & & $\begin{array}{l}-0.037 \\
(1.85)^{*}\end{array}$ \\
\hline Law and Order & & & $\begin{array}{l}-0.175 \\
(4.84)^{* * *}\end{array}$ & & & $\begin{array}{l}0.073 \\
(1.28)\end{array}$ \\
\hline GDP per capita & & & & $\begin{array}{l}-0.107 \\
(1.73)^{*}\end{array}$ & & $\begin{array}{l}0.009 \\
(0.17)\end{array}$ \\
\hline $\begin{array}{l}\text { Institutional } \\
\text { Development }\end{array}$ & & & & & $\begin{array}{l}-0.340 \\
(5.60)^{* * *}\end{array}$ & $\begin{array}{l}-0.585 \\
(4.14)^{* * *}\end{array}$ \\
\hline Pseudo $\mathrm{R}^{2}$ & 0.036 & 0.032 & 0.042 & 0.029 & 0.039 & 0.052 \\
\hline Observations & 5439 & 5184 & 4366 & 6153 & 6153 & 4032 \\
\hline
\end{tabular}




\section{Table A1}

\section{Country List}

\begin{tabular}{|c|c|c|c|c|c|c|}
\hline & $\begin{array}{r}\text { Number of } \\
\text { firms }\end{array}$ & $\begin{array}{r}\text { Private } \\
\text { Credit }\end{array}$ & $\begin{array}{l}\text { Value } \\
\text { Traded }\end{array}$ & $\begin{array}{r}\text { Law and } \\
\text { Order }\end{array}$ & $\begin{array}{l}\text { GDP per } \\
\text { capita I }\end{array}$ & $\begin{array}{r}\text { Institutional } \\
\text { Development }\end{array}$ \\
\hline Albania & 163 & & 0.00 & 3.63 & 807 & -0.71 \\
\hline Argentina & 100 & 0.17 & 0.04 & 4.13 & 8,000 & 0.33 \\
\hline Armenia & 125 & 0.04 & 0.00 & & 844 & -0.44 \\
\hline Azerbaijan & 128 & & 0.00 & & 408 & -0.78 \\
\hline Bangladesh & 50 & 0.22 & 0.01 & 2.13 & 339 & -0.39 \\
\hline Belarus & 125 & 0.06 & 0.00 & & 2,235 & -0.76 \\
\hline Belize & 50 & 0.41 & 0.00 & & 2,738 & 0.54 \\
\hline Bolivia & 100 & 0.40 & 0.00 & 2.13 & 939 & 0.02 \\
\hline Bosnia & 102 & & 0.00 & & 1,178 & -0.99 \\
\hline Botswana & 101 & 0.12 & 0.01 & 4.75 & 3,593 & 0.56 \\
\hline Brazil & 201 & 0.28 & 0.13 & 3.50 & 4,492 & 0.00 \\
\hline Bulgaria & 125 & 0.10 & 0.00 & 4.88 & 1,415 & 0.01 \\
\hline Cambodia & 326 & & & & 282 & -0.39 \\
\hline Cameroon & 57 & 0.14 & 0.00 & 2.75 & 631 & -0.73 \\
\hline Canada & 101 & 0.81 & 0.33 & 6.00 & 20,549 & 1.43 \\
\hline Chile & 100 & 0.59 & 0.08 & 4.50 & 5,003 & 0.87 \\
\hline China & 101 & 0.83 & 0.18 & 4.38 & 676 & -0.20 \\
\hline Colombia & 101 & 0.31 & 0.01 & 1.50 & 2,381 & -0.41 \\
\hline Costa Rica & 100 & 0.15 & 0.00 & 4.00 & 3,692 & 0.81 \\
\hline Cote d'Ivoire & 97 & 0.26 & 0.00 & 2.88 & 763 & -0.19 \\
\hline Croatia & 127 & 0.00 & 0.01 & & 3,845 & 0.03 \\
\hline Czech Republic & 137 & 0.57 & 0.10 & 5.80 & 5,159 & 0.68 \\
\hline Dominican Republic & 111 & 0.23 & 0.00 & 3.63 & 1,712 & -0.11 \\
\hline Ecuador & 100 & 0.21 & 0.01 & 4.00 & 1,538 & -0.32 \\
\hline Egypt & 102 & 0.33 & 0.02 & 3.13 & 1,108 & -0.15 \\
\hline El Salvador & 104 & 0.28 & 0.00 & 2.25 & 1,706 & -0.03 \\
\hline Estonia & 132 & 0.13 & 0.10 & & 3,663 & 0.61 \\
\hline Ethiopia & 105 & 0.20 & 0.00 & 3.00 & 109 & -0.12 \\
\hline France & 99 & 0.91 & 0.20 & 5.63 & 27,720 & 1.02 \\
\hline Georgia & 129 & & 0.00 & & 411 & -0.61 \\
\hline Germany & 100 & 1.00 & 0.32 & 6.00 & 30,794 & 1.37 \\
\hline Ghana & 119 & 0.05 & 0.00 & 3.00 & 393 & -0.14 \\
\hline Great Britain & 90 & 1.13 & 0.58 & 5.75 & 20,187 & 1.50 \\
\hline Guatemala & 106 & 0.15 & 0.00 & 2.38 & 1,503 & -0.50 \\
\hline Haiti & 103 & 0.11 & 0.00 & 1.88 & 369 & -1.14 \\
\hline Honduras & 100 & 0.26 & 0.02 & 2.75 & 708 & -0.43 \\
\hline Hungary & 129 & 0.33 & 0.01 & 5.38 & 4,706 & 0.87 \\
\hline India & 210 & 0.23 & 0.09 & 3.13 & 414 & 0.00 \\
\hline Indonesia & 99 & 0.47 & 0.08 & 3.88 & 1,045 & -0.76 \\
\hline Italy & 100 & 0.58 & 0.11 & 5.25 & 19,646 & 0.91 \\
\hline Kazakhstan & 127 & 0.09 & 0.00 & & 1,315 & -0.53 \\
\hline Kenya & 112 & 0.32 & 0.01 & 3.50 & 339 & -0.78 \\
\hline Kyrgyz Republic & 125 & 0.06 & 0.00 & & 800 & -0.42 \\
\hline Lithuania & 112 & 0.12 & 0.01 & & 1,908 & 0.26 \\
\hline Madagascar & 116 & 0.13 & 0.00 & 2.75 & 238 & -0.38 \\
\hline
\end{tabular}




\begin{tabular}{|c|c|c|c|c|c|c|}
\hline & $\begin{array}{r}\text { Number of } \\
\text { firms }\end{array}$ & $\begin{array}{r}\text { Private } \\
\text { Credit }\end{array}$ & $\begin{array}{l}\text { Value } \\
\text { Traded }\end{array}$ & $\begin{array}{r}\text { Law and } \\
\text { Order }\end{array}$ & $\begin{array}{l}\text { GDP per } \\
\text { capita I }\end{array}$ & $\begin{array}{r}\text { Institutional } \\
\text { Development }\end{array}$ \\
\hline Malawi & 55 & 0.11 & 0.00 & 2.88 & 154 & -0.17 \\
\hline Malaysia & 100 & 1.07 & 1.06 & 4.13 & 4,536 & 0.51 \\
\hline Mexico & 100 & 0.23 & 0.12 & 3.00 & 3,395 & -0.07 \\
\hline Moldavia & 125 & 0.06 & 0.04 & & 668 & -0.20 \\
\hline Namibia & 95 & 0.38 & 0.01 & 4.50 & 2,325 & 0.47 \\
\hline Nicaragua & 100 & 0.25 & & 3.00 & 435 & -0.41 \\
\hline Nigeria & 93 & 0.09 & 0.00 & 2.63 & 254 & -1.00 \\
\hline Pakistan & 103 & 0.23 & 0.07 & 2.38 & 506 & -0.59 \\
\hline Panama & 100 & 0.62 & 0.00 & 2.63 & 3,124 & 0.11 \\
\hline Peru & 108 & 0.12 & 0.04 & 2.25 & 2,335 & -0.18 \\
\hline Philippines & 100 & 0.36 & 0.15 & 2.88 & 1,126 & 0.21 \\
\hline Poland & 225 & 0.09 & 0.03 & 5.25 & 3,216 & 0.70 \\
\hline Portugal & 100 & 0.62 & 0.12 & 5.25 & 11,582 & 1.20 \\
\hline Romania & 125 & 0.09 & 0.00 & 4.38 & 1,372 & -0.08 \\
\hline Russia & 525 & 0.08 & 0.01 & 3.63 & 2,224 & -0.54 \\
\hline Senegal & 124 & 0.21 & 0.00 & 2.38 & 563 & -0.30 \\
\hline Singapore & 100 & 1.02 & 0.69 & 5.50 & 24,948 & 1.44 \\
\hline Slovakia & 129 & 0.29 & 0.07 & & 3,805 & 0.28 \\
\hline Slovenia & 125 & 0.23 & 0.02 & & 10,233 & 0.85 \\
\hline South Africa & 121 & 0.96 & 0.17 & 2.75 & 3,925 & 0.11 \\
\hline Spain & 104 & 0.80 & 0.35 & 5.38 & 15,858 & 1.11 \\
\hline Sweden & 102 & 1.12 & 0.40 & 6.00 & 28,258 & 1.53 \\
\hline Tanzania & 83 & 0.09 & 0.00 & 4.38 & 182 & -0.13 \\
\hline Thailand & 422 & 1.15 & 0.38 & 4.63 & 2,836 & 0.15 \\
\hline Trinidad and Tobago & 101 & 0.46 & 0.02 & 4.00 & 4,526 & 0.59 \\
\hline Tunisia & 52 & 0.60 & 0.01 & 3.88 & 2,200 & 0.30 \\
\hline Turkey & 150 & 0.14 & 0.16 & 3.63 & 2,994 & -0.33 \\
\hline Uganda & 137 & 0.03 & 0.00 & 2.88 & 324 & -0.34 \\
\hline Ukraine & 225 & 0.01 & 0.00 & & 867 & -0.58 \\
\hline Uruguay & 100 & 0.25 & 0.00 & 3.00 & 6,114 & 0.56 \\
\hline USA & 100 & 1.63 & 0.73 & 6.00 & 29,250 & 1.29 \\
\hline Uzbekistan & 125 & & 0.00 & & 448 & -1.04 \\
\hline Venezuela & 100 & 0.16 & 0.03 & 4.00 & 3,483 & -0.37 \\
\hline West Bank-Gaza & 93 & & 0.00 & & & \\
\hline Zambia & 84 & 0.06 & 0.00 & 2.88 & 394 & -0.20 \\
\hline Zimbabwe & 129 & 0.25 & 0.02 & 3.50 & 693 & -0.52 \\
\hline
\end{tabular}

